\title{
"I Reflect, Therefore I Am... a Good Professional". On the Relationship between Reflection-on-Action, Reflection-in-Action and Professional Performance in Vocational Education
}

\author{
Alberto A. P. Cattaneo ${ }^{1}$ (D) Elisa Motta $^{2}$
}

Received: 29 February 2020 / Accepted: 16 November 2020/ Published online: 8 December 2020

(C) The Author(s) 2020

\begin{abstract}
Reflection is essential for professional competence development in every profession. Reflection-on-action (taking place a posteriori, when the task is already accomplished) and reflection-in-action (occurring while performing the task) are equally important to increasing one's professionalism. Some evidence supports the effectiveness of promoting the former by using metacognitive prompts that encourage vocational education apprentices to reflect. However, it is unclear to what extent this approach is effective to promote their reflection-in-action, to increase the quality of their professional performance, and to establish a long-term attitude to reflect on-action. Using a thinking aloud technique, we asked 15 apprentice chefs to cook a recipe and video-recorded them. When finished, we asked them to complete a report that self-assessed their performance. Nine of them were accustomed to metacognitive prompts to reflect on their practice, the others not. The former group outperformed the latter in the quality of their reflection-in-action. Also, the quality of their performance, according to two experts' assessment, was significantly better. Finally, their reflection-on-action was higher. Despite its limitations due to the small sample, the study represents a good premise to confirm the effectiveness of our pedagogical approach and transfer it to other initial vocational education professions.
\end{abstract}

Keywords Reflection · Reflection-in-action · Reflection-on-action · Professional performance $\cdot$ Vocational education

Alberto A. P. Cattaneo

alberto.cattaneo@iuffp.swiss

1 Swiss Federal Institute for Vocational Education and Training, Lugano, Switzerland

2 Seregno, Italy 


\section{Introduction}

According to the experiential learning approach, learning is "the process whereby knowledge is created through the transformation of experiences" (Kolb 1984, p. 49). Starting from this general assumption, many scholars (e.g., Boud et al. 1985; Dewey 1933, 1938/1963; Engeström 1987; Kolb 1984; Moon 1999a; Schön 1983) agree that experience per se is not enough; to learn, one needs to reflect on experiences. In other words, reflection leads such transformation. This term covers a wide and deeply investigated concept (e.g., Thorsen and DeVore 2013 for an overview), which includes several more specific processes such as re-capturing, description, analysis, interpretation, accommodation, monitoring, debugging, evaluation and also "introspection" (e.g., Vermersch 2006, 2009). Boud et al. (1985), for example, define reflection as an "important human activity in which people recapture their experience, think about it, mull it over and evaluate it" (p.19); as a result, reflection plays both a cognitive and metacognitive role in learning (Looi and Wu 2015). Moreover, Schön's (1983) seminal work acknowledges that reflection is an essential trait of professionalism and competence and distinguishes between reflection-on-action and reflection-in-action, the former occurring a posteriori, the latter taking place whilst performing an activity or in a professional situation. This important source for competence development is particularly interesting for dual vocational education and training (VET) systems, such as the Swiss one (Bonoli et al. 2018; Strahm et al. 2016), which offers learners (apprentices) the opportunity to train at school while concurrently working in a company. However, reflecting on one's experiences is usually not spontaneous in vocational education (Stavenga de Jong et al. 2006; Taylor and Freeman 2011); it needs scaffolding provided by educators (De Bruijn and Leeman 2011; Schaap et al. 2012), who could appropriately utilise critical questions and prompts to support the reflective process (Raizen 1994; Krause and Stark 2010).

In a previous study on apprentice chefs, we showed that instructional activities fostering them to reflect on their job performance were effective. In particular, we demonstrated the effectiveness of promoting reflection-on-action through instructional activities based on prompts regarding declarative knowledge acquisition, metacognitive skills development, and attitude towards reflection (Cattaneo et al. 2015). Metacognition-here, the individuals' knowledge regarding cognitive processes and the application of this knowledge for controlling the same processes (Flavell 1979) — was taken in its components, including planning, monitoring, debugging, tentativeness of explanation (Schraw and Dennison 1994) as an indicator of reflection. However, three points were still missing:

1) To what extent is getting apprentices used to metacognitive prompts to reflect onaction also a way to promote their reflection-in-action? The underlying assumption is that becoming accustomed to reflecting on action can lead the reflective practitioner to adopt a reflective approach more easily also while acting, thus confirming that reflection on action is preliminary to reflection in action (e.g. Hatton and Smith 1995).

2) To what extent does reflecting on practices result in the improvement of their professional performance quality? We showed the effects of reflection on metacognitive skill development, but in the final analysis, we expect vocational 
students to develop their mastery in performing as professionals in practice. We therefore demonstrated that reflective practice improves practitioners' performance quality, as often stated (e.g. Roessger 2015).

3) To what extent does apprentices' exposure to reflection-oriented instructional activities reveal a long-term effect on reflection on-action? Apprentices participated in these reflection-oriented activities repeatedly over four semesters (from the second semester of the first year to the first semester of the third, final year of the curriculum), which should be enough time to internalise reflection as a habitus, a customary practice (Veenman 2011). With this third question - a delayed posttreatment measure - we checked if this was really the case or not.

These points represent the focus of the current study; we present their theoretical grounding in detail in the following section.

\section{Theoretical Framework}

\section{Reflection and the Distinction and Interplay between Reflection 'on-Action' and 'in-Action'}

The relationship between experience and reflection is a complex topic analysed in detail by scholars over the last decades. The terminology itself includes expressions related to 'reflexion' but also to 'reflective attitude', 'reflective learning', 'reflective practice', etc. Moon (2004) examined these two issues in-depth, proposing a thorough overview of the possible perspectives and their potential application in education. Mann et al. (2009) systematic review also provides us with a summary on these topics. They highlight how most of the reflective practice models begin from the common premise of "returning to an experience to examine it, deliberating intending that what is learned may be a guide in future situations, and incorporating it into one's existing knowledge" (p. 597). From this verification, the authors identify two major dimensions that serve as the basis for several models of reflections: an iterative dimension and a vertical dimension. The former-visible e.g. in Schön's 1983 and Boud et al. 1985 models-pertains to referencing a previous experience, which triggers reflection, producing new understandings that ideally prepare for a change in behaviour when facing future similar experiences. In these cases, it is the iterative process of reflection to be in the spotlight. The latter (e.g. in Mezirow 1991; Hatton and Smith 1995; Moon 1999 b) emphasises the fact that reflection can assume different levels, from surface levels, more descriptive than analytical, to deeper levels, more analytical, and able to present critical synthesis. Moon (1999b), for example, identifies five progressive levels in the reflective process: noticing, making sense, making meaning, working with meaning, and transformative learning. Similarly, Hatton and Smith (1995) claim that reflection reveals in a composition of various, progressive phases: description of experience, descriptive reflection, dialogic reflection, and finally critical reflection.

Scholars widely recognise reflective practice as an important trigger for sustaining professional competence development (e.g. Hetzner et al. 2011) and for fostering deep learning processes (e.g., Leung and Kember 2003), although they still advocate for further investigations to provide evidence on the relationship between reflective 
practice, on the one hand, and learning outcomes and professional development, on the other (Roessger 2015). They also claim that promoting reflection-on-action should be included as an important part of any curriculum (e.g., Bontemps-Hommen et al. 2020; Kember 2001; Moon 2004) and especially in VET also as a way to better articulate and connect the theoretical and practical parts of vocational curricula (Motta et al. 2013; Berglund et al. 2020; Cowan 2020). These general considerations lead us to design and investigate the effects of several instructional modalities aimed at enabling an effective reflective process in VET (e.g., Motta et al. 2014; Cattaneo and Boldrini 2016). However, in general, all the cases reported thus far refer to what Schön (1983) labelled "reflection-on-action", to distinguish it from "reflection-in-action".

In fact, Schön specified that the professional's reflective process does not take place only a posteriori, when the task is already accomplished, but it could also be incorporated into the actions, occurring at the beginning of it or during the process. After the accomplishment of a task, "we reflect on-action, thinking back on what we have done in order to discover how our knowing-in-action may have contributed to an unexpected outcome" (Schön 1983, p. 26). In so doing, learners become aware of what they have done, can self-evaluate their action, and make sense of experiences to orient themselves for current and future action. Reflection-on-action is a retrospective contemplation and analysis of previous practice to uncover the development of one's knowledge, used in a specific situation. The reflective practitioner compares the task accomplished with previous similar ones - analysing how the situation might have been managed differently - and pays attention to what needs to change in the future. Such a process can also benefit from collaboration with others, be they peers or tutors, to develop joint reflections (Bontemps-Hommen et al. 2020; Burhan-Horasanl1 and Ortaçtepe 2016; Lavoué et al. 2015; Motta et al. 2017).

Reflection-in-action, differently, happens when action and reflection are simultaneous: the learner constantly adjusts and changes the new information assimilated while performing. Reflecting in -action, practitioners can stop during an action, make necessary adjustments, make informed decisions, and, if necessary, change the way of accomplishing the task. "Distinguished reflection-in-action from other kinds of reflection is its immediate significance for action" (Schön 1987, p. 29). Given its characteristics, it is not surprising that capturing reflection-on-action is usually easier and more frequent than capturing reflection-in-action, as the latter is more demanding (Moghaddam et al. 2019; Zhu 2011). This makes "the need for nurturing reflectionin-action" (Zhu 2011, p. 772) necessary and particularly worthy of investigation. As reflection-in-action takes place while practicing, it is difficult to replicate it outside practice itself or to teach (Edwards 2017). One way may be to prepare students to reflect-in-action "by anticipating possible scenarios and various options in response" (Bell and Mladenovic 2013, p.9) and to refer to voiced inner dialogues - a form of reflection-on-action - as a "means of moving both individuals and the organisation towards reflection-in-action and reflexive engagement" (Holton and Grandy 2016, p.387). This brings us to introducing the question about the relationship between reflection-on-action and reflection-in-action.

Indeed, these two reflection processes are important for VET students to integrate the various types of knowledge they encounter in school- and workplace-based learning environments that constitute the basis of their professionalism (Baartman et al. 2018). The transformative integration of knowledge, skills and attitudes that characterise 
learning in vocational settings in fact relies on reflection (Baartman and de Bruijn 2011). The question is what kind of interaction exists between reflection in- and onaction.

Cowan (2017) proposes a model based on four types of reflection (he added reflection-for-action - an anticipatory reflection that precedes activity, and composting reflection, a second-order reflection arising from reconsidering previous reflective work). Although it is not clear which of the two anticipates the other, reflection onaction and in-action are evidently interconnected and reciprocally functional. The author also illustrated how linking various types of reflection is useful to generate significant learning outcomes, and he argued that complementary (types of) reflection tasks should be structured and that an electronic portfolio to collect them should be planned when designing learning courses. In a similar vein, in their study on Englishas-a-foreign-language teachers, Burhan-Horasanlı and Ortaçtepe (2016) showed how "reflective practice is an embedded process benefiting from the interplay of reflection on, in and for-action working together to lead to positive outcomes in teachers' practices and professional development at large" (p.379). Without initially distinguishing the two processes, Roessger (2015) stated that when dealing with professional learning contexts, any kind of reflection can happen if some prerequisites are already met. In particular, based on a conceptualisation of instrumental learning which foresees the progressive acquisition of "knows" (declarative knowledge), "moves" (motor skills), "knows-how" (procedural knowledge), "shows-how" (competence) and "does" (performance), the author stated that reflection can happen once some of these elements are internalised and automatised. For reflection-in-action to happen, in particular, some basis must already be acquired to be mobilised (in reflection-in-action) and applied across professional situations. For this transfer to happen, however, low complexity tasks and low cognitive load are needed. In this view, reflection-in-action can be considered the explicit expression of learning while also a means to reinforce and reconstruct that learning (Edwards 2017). Roessger (2015) and Edwards (2017) shared with other scholars (e.g. Hatton and Smith 1995; Tigelaar et al. 2017) the idea that reflecting on-action is a prerequisite for reflecting inaction, but they also both admit that "the notion that undertaking reflection-on-action assignments develops the reflection-in-action skills needed for [...] practice is not demonstrated in the literature" (Edwards 2017, p.1).

\section{Reflection and Metacognition}

Reflection is often a component of learning in its various forms (Moon 2004). In particular, reflection promotes learning outcomes in terms of knowledge and domain comprehension, critical revision, personal and professional continuous development, theory-building starting from the observation of practical situations, decision making, and reflection on the learning process itself (Moon 1999a, 1999b). From these and other considerations, one can see the close relationship between reflection and metacognition (see also Rose 2016), as the former encourages the latter. 'Metacognition' itself (Flavell 1979) is taken in its components as an indicator of reflection. The metacognitive learner is aware of the motives, task demands, personal cognitive resources, as well as exerts control over the strategies used to learn and act (Biggs 1988). Ertmer and Newby (1996) claim that metacognition facilitates the strategic 
performance of expert learners and that reflection provides the critical link between knowledge and control of the learning process. "By employing reflective thinking skills to evaluate the results of one's own learning efforts, awareness of effective learning strategies can be increased and ways to use these strategies in other learning situations can be understood" (p. 18). Similarly, Kolb conceives the control on reflective and metacognitive processes as a source for learning: "Deliberate experiential learning requires individual conscious metacognitive control of the learning process that enables monitoring and selecting learning approaches that work best in different learning situations" (Kolb 1984, p. 338).

In each of these contributions, a reference to metacognitive strategies, processes, and components is always explicit. According to Schraw and Dennison (1994), McKeachie (1987), and Volet et al. (2009), one can identify and summarise the main components of metacognitive activity and reflection (Kaune 2006) in the following: planning, monitoring, debugging, evaluation, and tentativeness of explanation. Planning refers to the allocation of resources prior to the activity; it regards goal setting, studying, and generating questions that anticipate the accomplishment of a task. Monitoring concerns the self-evaluation of strategies put into action during a cognitive activity; it includes self-testing of comprehension, using the correct material and strategies, as well as checking and correcting behaviours. Debugging includes strategies used to correct comprehension and performance errors. It relates to both the identification of mistakes and ways of correcting them. Evaluation consists of analysing the performance and effectiveness of enacted strategies following the activity. Tentativeness of explanation regards direct and indirect attempts to explain what one is thinking and doing or motivating one's choices.

Each component shows how learners can reflect and self-evaluate the completion of their tasks. Such indices are useful for reflecting in-action and on-action, although they can be attributed a general connotation towards one or the other (e.g., monitoring is easily identified during reflection-in-action; differently, debugging is easily identifiable during reflection-on-action).

\section{Writing to Reflect}

A traditional way to express reflection-on-action is writing (Moon 2004). Writing is effective both for "the comprehension and retention of information and concepts as well as reflections on ideas and conceptions" (Boscolo and Mason 2001, p. 84) and is a powerful learning tool (Schumacher and Gradwohl Nash 1991). According to Rosaen (1989), there are three main features of this mediation tool: 1) re-examination of one's expression of thoughts or experiences a posteriori; 2) objectification of one's thoughts to externalise them, thus allowing consciousness of how thoughts are reciprocally interconnected; and 3) ability to track experiences and thoughts to allow monitoring. Writing triggers more reflection on experience for learners than other tools; thus, learning journals continue to become a standard component of many curricula (Segev-Miller 2005; Moon 1999b). Journal writing, which is writing about one's experiences, allows the subject to "step-back" from the practice, "to reflect upon it and to return to it with understanding" (Lukinsky 1990, p. 213). The effectiveness of a learning journal increases with the use of various types of stimuli and prompts (Berthold et al. 2007; Kember 2001; Krause and Stark 2010) aimed at fostering reflection. 


\section{Reflective Writing in Initial VET: The Present Study}

In the VET context, researchers showed the effectiveness of journal writing in the development of reflective and professional competences as well as deep learning (Gavota et al. 2010; Ortoleva and Bétrancourt 2016; Motta et al. 2013). In particular, in a previous study with apprentice chefs (see Motta et al. 2014; Hämäläinen and Cattaneo 2015, for details), two intact classes from a vocational school in Ticino, Switzerland, worked through a series of instructional activities aimed at promoting metacognitive skills development. The activities began at the end of the first semester of the curriculum and continued through the apprenticeship until the beginning of the sixth, final semester. The learning activities and materials were exactly the same for both classes and conducted by the same teacher. Overall, the activities included ten plenary lessons of about four units each and four sessions organised around collaborative, small-group activities (see Cattaneo et al. 2015; Motta et al. 2017). Independent of the social organisation of the activities, they were all designed starting with the apprentices' learning journal entries. Moreover, they all promoted reflection on apprentices' practices using a set of reflective prompts the teacher provided to the students or directly integrated into the learning tasks. Based on a random selection, one class served as a baseline and used the traditional paper-based learning journal, while the other class - the experimental group - profited from a web-based environment (see Fig. 1), allowing the documentation of their professional workplace practice. We organised the environment as a personal recipe book. Each recipe, apart from the standard fields of ingredients, quantities, and steps, contained pictures of the workplace collected via mobile phones during work and a learning journal section with prompts that support reflection-on-action.

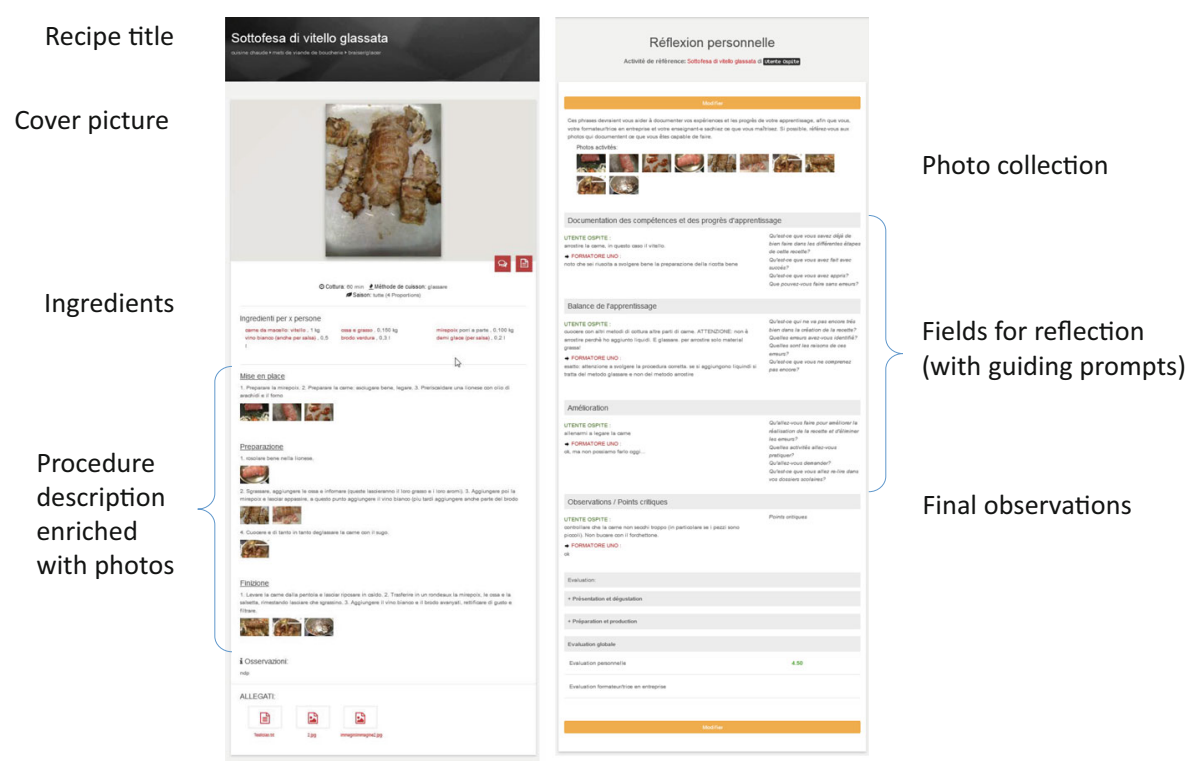

Fig. 1 The web-based environment for apprentice chefs to collect learning documentation as a personal recipe book. Each recipe (left) contained the necessary details and related photos. A reflection sheet organised around three main fields with reflective prompts (right) completed each recipe 
However, when this monitored experience came to its end, the three questions we anticipated in the introduction remained unanswered: the first, which is also raised in the literature (Edwards 2017; Roessger 2015), asks if accustoming apprentices to reflection-on-action also promotes their reflection-in-action; the second, which has been investigated in other contexts (Hetzner et al. 2011; Cowan 2020), asks for evidence that reflecting improves apprentices' professional performance; and the third asks the extent to which a long-lasting, reflection-oriented intervention like this one reveals an effect on the capacity to reflection on-action in the long term.

\section{Method}

\section{Sample}

The study involved 16 apprentice chefs (age: $\mathrm{M}=19.3, \mathrm{SD}=2.50 ; 25 \%$ females), who voluntarily took part in the study and received no compensation for participating. Nine of them belonged to the experimental class - who then constituted the experimental group for this study as well - and the remaining seven to the control group class - who constituted the control group. Eight of them came directly from middle school: four after one year spent in another curriculum, two after two years, and another two after more than two years. The composition of the two groups controlled for school performance (good, fair and weak learners were all represented) and characteristics of the workplace (both mensas and gourmet restaurants were represented) so that the two groups were equally heterogeneous, although not systematically differing in characteristics that may have an influence on the outcome variables.

\section{Procedure}

Each apprentice had a professional workstation at their disposal and received an invitation to prepare and serve a given recipe. The name of the recipe (chopped Zürich-style chicken) was unknown to the apprentice until the procedure began. The recipe was chosen from a list of recipes eligible for the final certification, meaning that its complexity was adequate for third-year apprentices. The time allocated for completing the task was $25 \mathrm{~min}$. The researchers video-recorded the entire procedure with a camera set in the workstation. All the required ingredients were available to save time, the teachers prepared them in advance. While cooking individually, the observing researcher directed apprentices to think aloud, that is, to verbalise what they were doing, including thoughts, ideas, etc. The think-aloud method is currently accepted by the psychological community as a useful method for accessing information on cognitive processes (van Someren et al. 1994), so it can be adopted for accessing reflection-in-action. It derives from older introspection methods used to collect data regarding subjects' conscious experiences. Thinking aloud consists of a practice task; individuals are instructed to think aloud while they are working on a specific task while researchers try not to interfere in the flow nor interrupt their work. The request to talk aloud "is repeated if necessary... thus encouraging the subject to tell what he or she is thinking. ... The subject keeps on talking, speaks out loud whatever thoughts come to mind while performing the task 
at hand" (van Someren et al. 1994, p. 26). Accordingly, if apprentices stopped speaking, the researchers prompted them to speak again with neutral "emptycontent" questions and requests, such as "And now, what are you thinking about?", "What are you paying attention to?" and "Please, continue telling me what are you thinking about" (Rogers 1961; Vermersch 2006). The benefit of the think-aloud method is that it reduces risks due to memory decay as well as bias due to retrospective reconstruction (Birch and Whitehead 2020), as it reveals what is happening in a participant's short-term working memory (Cowan 2019). However, the risk of applying this methodology is that thinking aloud may split a participant's attention between narrating, thinking and doing, thus generating an excessive cognitive load (Ericsson and Simon 1980).

After serving the course on a dish, the apprentice moved to an adjoining room to complete a paper-and-pencil report to self-assess her performance and mastery of the professional procedure. In reference to the cooked recipe, the researcher tasked apprentices to identify: the key points for a correct mise en place, the key points for a correct preparation of the dish, the key points for a correct finition, the skills already mastered in the recipe, the skills they still need to learn, what needs improvement, and what needed their attention to complete the procedure.

\section{Measures}

To answer the first research question, we looked at the quality of the apprentices' reflection-in-action. We analysed the transcriptions of their speech using NVivo software and looked for indices of metacognitive processes. According to Schraw and Dennison (1994) and McKeachie (1987), we developed a coding scheme (see details in Table 1) with the following categories: planning, monitoring, evaluation, debugging, and tentativeness of explanation. Two researchers initially applied the coding scheme to a subset (about 20\%) of the corpus randomly extracted from the dataset. A first inter-rater reliability analysis, run to determine consistency among the raters, yielded a substantial inter-rater agreement value (Cohen's Kappa $=0.654$ ). As this value was not fully satisfactory, both researchers engaged in a discussion on the discrepancies to clarify ambiguities that both coders could agree upon.

To answer the second research question on the effects reflection has on the quality of professional performance, we asked two experts (both were professional chefs as well as vocational teachers of professional subject matter) to rate the apprentice's performance. The experts received the video recordings of the performance and rated it using a grid similar to the one used in official cooking competitions, which includes 27 indicators. The indicators, grouped into the three main steps used by chefs to describe a recipe, include mise en place (e.g., choice of tools, suitable for preparation/for quantity), preparation (e.g., choice of heat source over casseroles; respect of the cooking method), and finition (e.g., uses suitable garnishes, proportions are respected, etc.). The experts assessed each indicator through a 5-point Likert-scale (from $1=$ absolutely not respected to $5=$ fully respected). The intraclass correlation coefficient, calculated applying a two-way mixed model with measures of absolute agreement, was excellent (ICC with 95\% confidence interval $=0.900(0.878-0.917))$.

To answer the third research question on the apprentice's long-lasting capacity to reflect-on-action, we utilised their paper-pencil reports by applying the same coding 
Table 1 Coding scheme for the analysis of the thinking aloud protocols and reports, with definitions and examples

\begin{tabular}{|c|c|c|c|}
\hline & References & Definitions (used for coding) & Examples of coding \\
\hline Planning & $\begin{array}{l}\text { 'Planning, goal setting, and } \\
\text { allocating resources prior } \\
\text { to learning.' } \\
\text { (Schraw and Dennison } \\
\text { 1994). } \\
\text { 'Setting goals for studying, } \\
\text { skimming, generating } \\
\text { questions before reading } \\
\text { the text, and doing a task } \\
\text { analysis of the problem. } \\
\text { All these activities help the } \\
\text { learner plan the use of } \\
\text { strategies and the } \\
\text { processing of information' } \\
\text { (McKeachie 1987). }\end{array}$ & $\begin{array}{l}\text { - Definition of goals and } \\
\text { means to reach it. } \\
\text { - Definition of what to do in } \\
\text { the task, making the list } \\
\text { about the step to reach the } \\
\text { final aim (making plans). } \\
\text { - Presence of dimension of } \\
\text { future, about what to do } \\
\text { later on, after what the } \\
\text { apprentices are doing now. } \\
\text { - Declaration of intention } \\
\text { about what they are going } \\
\text { to do afterwards. } \\
\text { - Thoughts/evaluation de- } \\
\text { clared what they had to do } \\
\text { better/should do in the } \\
\text { close and forthcoming fu- } \\
\text { ture. } \\
\text { - Prevision/evaluation (future } \\
\text { dimension) of crucial } \\
\text { points: they foresee crucial } \\
\text { points although they have } \\
\text { never faced them, but just } \\
\text { referring to the informa- } \\
\text { tion they got at school. }\end{array}$ & $\begin{array}{l}\text { - When reading the recipe: } \\
\text { 'the first thing I have to do } \\
\text { is chopping the onions' } \\
\text { - 'I am thinking about what I } \\
\text { have to do later on, I have } \\
\text { to chop mushrooms, too'. } \\
\text { - 'I put them in the middle, } \\
\text { and then I put it over the } \\
\text { meat'. } \\
\text { - 'I'll pan fry the chicken, } \\
\text { with flour, dressed with oil } \\
\text {-sunflower oil- and then } \\
\text { I'll do mushrooms with } \\
\text { butter and onions. I'll } \\
\text { simmer with white wine, } \\
\text { I'll put the demi-glass, the } \\
\text { cream and then at the end } \\
\text { the parsley and salt'. } \\
\text { - 'I think I'll do... little } \\
\text { slivers, so it is ok with the } \\
\text { crumbled. I'll not stew too } \\
\text { much because they are } \\
\text { already thin...' }\end{array}$ \\
\hline Monitoring & $\begin{array}{l}\text { 'Assessment of one's } \\
\text { learning or strategy use' } \\
\text { (Schraw and Dennison } \\
\text { 1994). } \\
\text { 'Self- monitoring during any } \\
\text { cognitive activity. } \\
\text { Monitoring activities } \\
\text { include tracking of } \\
\text { attention as one read, self- } \\
\text { testing (while reading a } \\
\text { text) to ensure compre- } \\
\text { hension of the material } \\
\text { and use of certain kinds of } \\
\text { test-talking strategies. ... } \\
\text { Self-regulation activities } \\
\text { are related to monitoring } \\
\text { activities. ... These } \\
\text { self-regulated activities are } \\
\text { assumed to improve per- } \\
\text { formance by assisting } \\
\text { learners in checking and } \\
\text { correcting their behaviour } \\
\text { as they proceed on task } \\
\text { (McKeachie 1987). }\end{array}$ & $\begin{array}{l}\text { - Identification of criteria to } \\
\text { check if the task is going } \\
\text { on as previously foreseen } \\
\text { by the apprentice or by the } \\
\text { recipe. } \\
\text { - Identification of crucial } \\
\text { points/mistakes without } \\
\text { mentioning any modality } \\
\text { to solve them. } \\
\text { - Identification of something } \\
\text { which they should not do. } \\
\text { - Identification of everything } \\
\text { which the apprentices } \\
\text { have to pay attention to in } \\
\text { the task accomplishment: } \\
\text { what they have to do, what } \\
\text { they have not to do while } \\
\text { they are in-action. } \\
\text { - Presence of dimension of } \\
\text { past, in terms of a result } \\
\text { they get, or in checking } \\
\text { whether what they are } \\
\text { doing is correct. } \\
\text { - Checking of procedure } \\
\text { steps, also from the } \\
\text { non-verbal point of view, } \\
\text { as tasting food or verifying }\end{array}$ & $\begin{array}{l}\text { - (...and what are you paying } \\
\text { attention to?) Not to cut } \\
\text { myself'. } \\
\text { - (reading the recipe) 'I was } \\
\text { checking the ingredients } \\
\text { not to forget anything } \\
\text { around'. } \\
\text { - 'I think about the cooking } \\
\text { method I have to do, about } \\
\text { the amount of foods I use, } \\
\text { and ...about what I should } \\
\text { do, and then to take care } \\
\text { that the mushrooms do not } \\
\text { stick to the pot'. } \\
\text { - (opening the cover) 'I add } \\
\text { some wine as it seems it } \\
\text { was missing'. } \\
\text { - 'ah, the lemon is missing... } \\
\text { it's the lemon which has to } \\
\text { be added'. } \\
\text { - 'checking the butter'. } \\
\text { - (Tasting). 'Always tasting } \\
\text {...' } \\
\text { - 'the mushrooms are too } \\
\text { much for this pot'. } \\
\text { - Tasting the mushroom in } \\
\text { order to add salt or not. }\end{array}$ \\
\hline
\end{tabular}


Table 1 (continued)

\begin{tabular}{|c|c|c|c|}
\hline \multicolumn{2}{|r|}{ References } & \multirow{2}{*}{$\begin{array}{l}\text { Definitions (used for coding) } \\
\text { if the tools are working in } \\
\text { the right way. } \\
\text { - Being aware of doing } \\
\text { something in the wrong } \\
\text { way, without finding the } \\
\text { way to solve the problem, } \\
\text { to repair the mistake. }\end{array}$} & \multirow{2}{*}{$\begin{array}{l}\text { Examples of coding } \\
\text { - Reading of the recipe } \\
\text { during the } \\
\text { accomplishment. } \\
\text { - Checking the clock to verify } \\
\text { if they are on time or not. }\end{array}$} \\
\hline & & & \\
\hline Debugging & $\begin{array}{l}\text { 'Strategies used to correct } \\
\text { comprehension and } \\
\text { performance error' } \\
\text { (Schraw and Dennison } \\
\text { 1994). }\end{array}$ & $\begin{array}{l}\text { - Identification of a bug, a } \\
\text { problem and also of the } \\
\text { possible way to solve the } \\
\text { problem. } \\
\text { Difference with monitoring: } \\
\text { If they only mention the } \\
\text { bug, it is monitoring; if } \\
\text { they find the way to solve } \\
\text { the problem, it is } \\
\text { debugging. }\end{array}$ & $\begin{array}{l}\text { - 'And so, I add the butter } \\
\text { here and not before, and I } \\
\text { did a mistake as it was } \\
\text { burning'. } \\
\text { - 'I'm thinking about how to } \\
\text { turn it (he identified the } \\
\text { problematic point) and } \\
\text { I'm finding the solution for } \\
\text { this point (he goes to take } \\
\text { a cover in order to turn } \\
\text { it)'. } \\
\text { - 'In the case it is quite } \\
\text { burned, so it is an XXX. } \\
\text { And I should immediately } \\
\text { change the pot'. } \\
\text { - I put too little oil, so we } \\
\text { need to add it!'. }\end{array}$ \\
\hline Evaluation & $\begin{array}{l}\text { 'Analysis of performance and } \\
\text { strategies effectiveness } \\
\text { after learning episode' } \\
\text { (Schraw and Dennison } \\
\text { 1994). }\end{array}$ & $\begin{array}{l}\text { - Identification of } \\
\text { weaknesses, one's own, } \\
\text { general. } \\
\text { - Identification of learning } \\
\text { needs (I have to } \\
\text { improve....). } \\
\text { - Explanation of the way they } \\
\text { realized a step or the } \\
\text { overall task, expressing } \\
\text { the level of satisfaction. } \\
\text { - Explanation of something } \\
\text { they could have done but } \\
\text { they did not do. }\end{array}$ & $\begin{array}{l}\text { - 'Everything I am doing it's } \\
\text { a big stupid thing. I don't } \\
\text { know, I could do it better'. } \\
\text { - 'I'm not the boss/king of } \\
\text { rosties'. } \\
\text { - 'I could have cooked the } \\
\text { chicken in a better way, } \\
\text { maybe in another pot; and } \\
\text { also, the rosti, I could } \\
\text { cook them'. } \\
\text { - 'It's quite easy!' } \\
\text { - 'And now it's going well'. } \\
\text { - 'I screwed up' }\end{array}$ \\
\hline $\begin{array}{l}\text { Tentativeness } \\
\text { of } \\
\text { explanation }\end{array}$ & $\begin{array}{l}\text { Direct and indirect } \\
\text { tentativeness to explain } \\
\text { what they are thinking, } \\
\text { motivating the choices } \\
\text { (Volet et al. 2009). }\end{array}$ & $\begin{array}{l}\text { - Explanation of the specific } \\
\text { step of the task the } \\
\text { apprentices are } \\
\text { accomplishing and } \\
\text { managing. } \\
\text { - Simple explanation which } \\
\text { gives the motives and } \\
\text { details about a specific } \\
\text { step. } \\
\text { - Articulated and theoretical } \\
\text { explanation about the } \\
\text { reasons why apprentices } \\
\text { are accomplishing /did the } \\
\text { process in that way. }\end{array}$ & $\begin{array}{l}\text { - 'I have to add the salt } \\
\text { because it was missing'. } \\
\text { - '...I put it, so it is already } \\
\text { done and ready'. }\end{array}$ \\
\hline
\end{tabular}


scheme on metacognitive indices presented above directly to the text produced by the apprentices after the performance.

To compute the differences between the two groups, we ran a Mann-Whitney test due to the small sample (Field 2018). Following Rosenthal (1991), the thresholds considered to interpret the effect size were the following: small below 0.3 , medium between 0.3 and 0.5 , and large over 0.5 .

\section{Results}

Regarding the apprentices' reflection-in-action, analysis showed that the experimental group outperformed the control group including all the sub-categories $\left(\mathrm{Mdn}_{\exp }=89.00\right.$ and $\mathrm{Mdn}_{\mathrm{con}}=53.00$ ), and in four of the five categories considered individually (Evaluation: $\mathrm{Mdn}_{\exp }=3.00, \mathrm{Mdn}_{\text {con }}=1.00$; Monitoring: $\operatorname{Mdn}_{\exp }=37.00, \operatorname{Mdn}_{\text {con }}=26.00$; Planning: $\operatorname{Mdn}_{\exp }=16.00, \operatorname{Mdn}_{\text {con }}=7.00$; and Tentativeness of explanations: $\operatorname{Mdn}_{\exp }=$ $30.00, \mathrm{Mdn}_{\mathrm{con}}=12.00$ ). Details are available in Table 2.

Regarding the quality of professional performance, the analysis by the two experts revealed the performance of the experimental apprentices to exceed the control group's performance. The researchers confirmed this analysis by considering the overall performance $\left(\mathrm{Mdn}_{\mathrm{exp}}=3.74 ; \mathrm{Mdn}_{\mathrm{con}}=2.53\right)$ and each single step of the procedure: mise en place $\left(\mathrm{Mdn}_{\exp }=3.85 ; \mathrm{Mdn}_{\text {con }}=2.95\right)$, preparation $\left(\mathrm{Mdn}_{\exp }=3.61 ; \mathrm{Mdn}_{\text {con }}=2.50\right)$ and finition $\left(\mathrm{Mdn}_{\exp }=4.00 ; \mathrm{Mdn}_{\mathrm{con}}=2.00\right)$. Details on the Mann-Whitney tests are reported in Table 3 .

Concerning the apprentices' quality of reflection-on-action, measured through the analysis of their written report after their performance, the overall measure-inclusive of all the metacognitive processes - was again significantly higher for the experimental group $\left(\mathrm{Mdn}_{\mathrm{exp}}=19.00 ; \mathrm{Mdn}_{\mathrm{con}}=14.00\right)$. Considering every single dimension,

Table 2 Differences in the quality of reflection-in-action, measured through the frequency of metacognitive processes indices in the thinking aloud protocols, between the experimental and the control group (MannWhitney test)

\begin{tabular}{|c|c|c|c|c|c|c|c|c|}
\hline & $\mathrm{Mdn}_{\exp }$ & $\mathrm{IQR}_{\exp }$ & $\mathrm{Mdn}_{\mathrm{ctrl}}$ & $\mathrm{IQR}_{\mathrm{ctrl}}$ & $\begin{array}{l}\text { Mann- } \\
\text { Whitney U }\end{array}$ & $\begin{array}{l}\text { Mann- } \\
\text { Whitney Z }\end{array}$ & $\begin{array}{l}p \\
\text { (two tailed) }\end{array}$ & $\begin{array}{l}\text { Effect size } \\
\text { (Rosenthal's } r \text { ) }\end{array}$ \\
\hline $\begin{array}{l}\text { In-action: } \\
\text { Overall }\end{array}$ & 89 & 43 & 53 & 18 & 0.0 & -3.337 & $<.001$ & -0.83 \\
\hline $\begin{array}{l}\text { In-action: } \\
\text { Debugging }\end{array}$ & 2 & 4 & 2 & 1 & 27.5 & -0.439 & .681 & -0.11 \\
\hline $\begin{array}{l}\text { In-action: } \\
\text { Evaluation }\end{array}$ & 3 & 4 & 1 & 4 & 12.5 & -2.028 & .042 & -0.51 \\
\hline $\begin{array}{l}\text { In-action: } \\
\text { Monitoring }\end{array}$ & 37 & 17 & 26 & 13 & 8.5 & -2.436 & .012 & -0.61 \\
\hline $\begin{array}{l}\text { In-action: } \\
\text { Planning }\end{array}$ & 16 & 10 & 7 & 5 & 9.0 & -2.394 & .016 & -0.60 \\
\hline $\begin{array}{l}\text { In-action: } \\
\text { Tentativeness } \\
\text { of explanation }\end{array}$ & 30 & 26 & 12 & 14 & 9.5 & -2.330 & .016 & -0.58 \\
\hline
\end{tabular}

Measured through the frequency of metacognitive processes indices in the thinking aloud protocols, between the experimental and the control group (Mann-Whitney test). Rosenthal's $r=\mathrm{Z} / \sqrt{N}$ (see Field 2018, p. 295) 
Table 3 Differences in the quality of performance between the experimental and control groups (MannWhitney test)

\begin{tabular}{|c|c|c|c|c|c|c|c|c|}
\hline & $\mathrm{Mdn}_{\mathrm{exp}}$ & $\mathrm{IQR}_{\exp }$ & $\mathrm{Mdn}_{\mathrm{ctrl}}$ & $\mathrm{IQR}_{\mathrm{ctrl}}$ & $\begin{array}{l}\text { Mann- } \\
\text { Whitney U }\end{array}$ & $\begin{array}{l}\text { Mann- } \\
\text { Whitney Z }\end{array}$ & $\begin{array}{l}P \\
\text { (two tailed) }\end{array}$ & $\begin{array}{l}\text { Effect size } \\
\text { (Rosenthal's } r \text { ) }\end{array}$ \\
\hline Mean Overall & 3.74 & .30 & 2.54 & .55 & 3.0 & -3.019 & .001 & -0.75 \\
\hline $\begin{array}{l}\text { Mean Mise en } \\
\text { place }\end{array}$ & 3.85 & .60 & 2.95 & 1.05 & 4.0 & -2.913 & .002 & -0.73 \\
\hline Mean Preparation & 3.61 & .53 & 2.50 & .56 & 4.0 & -2.915 & .002 & -0.73 \\
\hline Mean Finition & 4.00 & 1.16 & 2.00 & .81 & 1.0 & -3.231 & $<.001$ & -0.81 \\
\hline
\end{tabular}

however, only the monitoring component resulted in significantly more frequency $\left(\mathrm{Mdn}_{\mathrm{exp}}=8.00 ; \mathrm{Mdn}_{\mathrm{con}}=5.00\right)$ in the experimental group. The monitoring dimension was the leading element for the overall measure. Details on the tests are available in Table 4.

Interestingly, while evaluating the data for interrelationship between our primary three measures, a Spearman's non-parametric correlation analysis showed positive and significant correlations between reflection-in-action and reflection-on-action $\left(r_{\mathrm{s}}(14)=\right.$ $.584, p=.017)$ and between reflection-in-action and the quality of the performance $\left(r_{\mathrm{s}}(14)=.781, p<.0001\right)$.

\section{Discussion and Conclusion}

In dual vocational education, apprentices can profit from a wide range of opportunities to learn at the workplace, but they have no time to reflect on them (Aarkrog 2005), as a good professional should do (Schön 1983). This opportunity can take place at school, especially when authentic traces of professional experiences are available to apprentices

Table 4 Differences in the quality of reflection-on-action, measured through the frequency of metacognitive processes indices in the written reports, between the experimental and the control group (Mann-Whitney test)

\begin{tabular}{lllllllll}
\hline & $\mathrm{Mdn}_{\text {exp }}$ & $\mathrm{IQR}_{\text {exp }}$ & $\mathrm{Mdn}_{\text {ctrl }}$ & $\mathrm{IQR}_{\text {ctrl }}$ & $\begin{array}{l}\text { Mann- } \\
\text { Whitney }\end{array}$ & $\begin{array}{l}\text { Mann- } \\
\text { Whitney Z }\end{array}$ & $\begin{array}{l}p \\
\text { (two tailed) }\end{array}$ & $\begin{array}{l}\text { Effect size } \\
\text { (Rosenthal's } r \text { ) }\end{array}$ \\
\hline $\begin{array}{l}\text { On action: } \\
\text { Overall }\end{array}$ & 19 & 7 & 14 & 4 & 9.0 & -2.407 & .016 & -0.60 \\
$\begin{array}{c}\text { On action: } \\
\text { Debugging }\end{array}$ & 0 & 1 & 0 & 1 & 29.0 & -0.325 & .837 & -0.08 \\
$\begin{array}{c}\text { On action: } \\
\text { Evaluation }\end{array}$ & 4 & 3 & 3 & 3 & 23.5 & -0.861 & .408 & -0.72 \\
$\begin{array}{c}\text { On action: } \\
\text { Monitoring }\end{array}$ & 8 & 6 & 5 & 2 & 9.5 & -2.348 & .016 & -0.59 \\
$\begin{array}{c}\text { On action: } \\
\text { Planning }\end{array}$ & 5 & 3 & 4 & 2 & 20.5 & -1.186 & .252 & -0.30 \\
\hline
\end{tabular}

Measured through the frequency of metacognitive processes indices in the written reports, between the experimental and the control group (Mann-Whitney test) 
so that reflection leads to the process of transforming experiences into learning. Based on this premise, in previous studies conducted on vocational education (e.g. Cattaneo et al. 2015; Motta et al. 2017), we demonstrated the effectiveness of integrating metacognitive prompts in learning activities at school in order to sustain reflectionon-action. However, those studies were unable to show whether apprentices' habitual reflection-on-action can also promote their reflection-in-action, improve their professional performance, and sustain the capacity to reflect on-action in the long term.

Regarding the first issue, adopting a thinking aloud approach, the current study showed that apprentices accustomed to reflection-on-action also developed a better performance in reflection-in-action. This is consistent with a conception of reflectionon-action as a prerequisite to developing reflection-in-action (e.g. Hatton and Smith 1995; Tigelaar et al. 2017). Chef apprentices in the experimental group repeatedly trained themselves to reflect-on-action both during the learning activities in class and when using the online learning environment to develop their learning documentation in the form of a recipe book. One of the most intuitive principles of learning, repetita iuvant (e.g. Rock 1958; Weibell 2011), may be the simplest way to comment on this result, especially if adopting spaced repetition (e.g. Kang 2016), as the class activities did. Apprentices internalised the habit to reflect, which made it easier for them to access the reflection mechanisms when prompted to do so by thinking aloud. This result which fills a gap in the literature reported by Roessger (2015) and Edwards (2017) proved to be true for four of the five metacognitive skills adopted as indices of the reflection process. The only one which was not significant with respect to the control group is debugging, probably the most illustrative metacognitive skill for reflection-inaction, which requires a high amount of resources to be put into action. Moreover, in our coding scheme, debugging requires not only the identification of the bug-in this case overlapping to monitoring - but also the mentioning of how to solve it, thus resulting in a more difficult, bi-faceted element.

When dealing with the influence of reflection on professional performance, similarly, those accustomed to reflecting on their experiences were better at performing their professional activity in each of the three main parts chefs used to code a recipe-mise en place, preparation, and finition - according to the assessment of two expert professionals. Although we did not refer to this measure in this study, this result is consistent with a previous study involving baker apprentices (Schwendimann et al. 2018), which adopted an approach like the one presented here to show how reflection positively correlated with the results bakers obtained in the final qualification exams, especially the practical part.

The idea that sustaining reflection-on-action during the apprenticeship induces a sort of lasting capacity to reflect in the long term is only partially confirmed. Although the general measure we adopted shows a significant difference in favour of the experimental group, looking at the details we can see that only the monitoring component really makes a difference, while the other components do not. We can find a possible explanation for this by looking at the texts produced by the apprentices. They tended to answer in a detailed manner, especially those questions on the self-assessment report asking them to indicate what they had to pay attention to in the different phases of the recipe. These questions are indeed explicitly related to the 'monitoring' code. With the other answers being more concise, the difference among the two groups tends to diminish or are more difficult to ascertain. 
Considering the results as a whole, one further consideration is worth mentioning. One might expect more pronounced differences between reflection-on-action and inaction. In fact, the reflection-on-action quality measured in the delayed ex-post report was different between the two groups only for monitoring, while it was different for all three components of reflection-in-action. We showed that monitoring is a typical metacognitive component of reflection-in-action. In this sense, the experimental group's superior ability to reflect in-action may have fed its ability to monitor its reflection on-action. However, the two groups' negligible difference in reflection-onaction may be due to the intervention being well balanced in the two classes, differing only in the web-based environment for the experimental class. The effectiveness of this environment in promoting metacognitive skills is evident in previous studies (e.g. Cattaneo et al. 2015; Mauroux et al. 2016). What emerged here - although it should be further and more directly investigated - is the possible influence of e-portfolios on reflection-in-action, which could be due to the exploitation of apprentices' experiences at the workplace (Schwendimann et al. 2015) and to the visual affordances of the pictures used to document their practice (Cattaneo and Aprea 2018).

Against these positive results, the study also presents some limitations. First, the choice to conduct it in an authentic setting exposed us to additional restrictions, as we cannot be sure to control for all the possible intervening variables influencing the development of reflection. Therefore, the interpretations given above - and in particular the possibility to generalize them - should anyway be considered cautiously. Although we tried to control for this variable, for example, in both classes there were more and less experienced apprentices, depending on the circumstances they encountered at the different workplaces where they are active. This could have an influence on their ability to think aloud and produce explanations concerning the procedure. Also, the choice of an authentic setting had an impact on the sample size, which was limited. Because of the complexity of the logistics and organisational aspects, we utilised the professional workstations of the vocational centre, which also provided us all the necessary ingredients, but were limited: only a subset of the two classes could take part in this study and not the entirety of the classes. Third, the same choice of the thinking aloud method could expose the study to some critics, as thinking aloud requires many cognitive resources and imposes a high cognitive load that could obstruct and slow down the professional performance. ${ }^{1}$ Similarly, the presence of video cameras during the performance as well as of the researcher stimulating their verbalisation could influence the naturalness of the apprentices' activity.

Despite these limitations, the pedagogical approach we used to foster reflection with chef apprentices showed to be effective for the experimental class for reflection-on-action in the short term (as shown in Cattaneo et al. 2015), for its delayed effects in the long term and for reflection-in-action while cooking. Moreover, the current study shows that reflection is not only effective for sustaining declarative learning acquisition and metacognitive skills development, as shown in the previous study, but also has effects on practice and the mastery of

\footnotetext{
${ }^{1}$ This said, however, the thinking aloud method proved to be a valid strategy to verify the apprentices' awareness of the strategies they put into action while performing a professional task. None of them reported the task to be too demanding, thus confirming for them the possibility to manage verbalisation of cognitive processes without interrupting the professional performances.
} 
professional tasks. To what extent these results can be generalised, however, is still questionable given the limitations mentioned above. Further research is needed for stronger evidence on the causal relation between the instructional intervention we proposed, its results on reflection and the relation between the two components of reflection. The same is true for the relationship between reflection and performance. For example, looking at data on reflection-in-action, one might suppose that - as discussed in the section on the theoretical framework - the debugging component of reflection may mostly conduce performance, as it does not stop at identifying the bug but also addresses how to solve it. These relationships between the dimensions of reflection-in-action and the quality of performance could be revealing and should be investigated further.

The results of this study must be read in light of the overall approach to which this specific experience refers. In fact, this study allows us to further elaborate the picture on how technologies can be exploited to better articulate the gap that apprentices experience between learning in school and learning at the workplace through an experiential learning approach (see Schwendimann et al. 2015). In this respect, we confirmed and extended the effectiveness of our pedagogical model to include professional expertise: the approach is effective both on knowledge acquisition and on skill mastery. This conclusion is important as it opens the possibility to transfer the same approach to other professional domains as a new way to support apprentices through reflective activities that improve awareness of the relationship between the theoretical and practical, as well as declarative and procedural, knowledge they encounter in diverse learning contexts, to build a unique and overall set of professional competences. In this sense, this study has implications for future research by making new insights into the relationship between reflection on- and in-action and between reflection and practice. Its results suggest further investigating these relationships to better understand their reciprocal influences. Most of all, however, it has implications for practice: we previously commented on the fact that often apprentices have no time to reflect at the workplace; our results show that giving apprentices some time to reflect is also in the interest of the employer, as it reflects directly on performance. The study also suggests suitable ways to foster reflection in vocational education by writing about one's practice and by exploiting technology, confirming and extending the results of other studies in the VET field (e.g. Cattaneo et al. 2020; Boldrini and Cattaneo 2014; Gavota et al. 2010; Mauroux et al. 2014, 2016; Ortoleva et al. 2016; Schwendimann et al. 2018). The same approach can be transferred to other professional fields to design effective instructional activities and learning environments capable of helping apprentices to develop those reflective skills, which are increasingly necessary for autonomous professionals and lifelong learners in the continuously evolving world of work.

Availability of Data and Material Data are available upon justified request after publication.

Code Availability Not applicable.

Funding Open Access funding provided by Swiss Federal Institute for Vocational Education and Training (SFIVET). This study was funded by the Swiss State Secretariat of Education, Research and Innovation (SERI). Contract Nr. BB.2013.0098 - REF-1131-31403. 


\section{Compliance with Ethical Standards}

Conflict of Interest The authors declare that they have no conflict of interest.

Open Access This article is licensed under a Creative Commons Attribution 4.0 International License, which permits use, sharing, adaptation, distribution and reproduction in any medium or format, as long as you give appropriate credit to the original author(s) and the source, provide a link to the Creative Commons licence, and indicate if changes were made. The images or other third party material in this article are included in the article's Creative Commons licence, unless indicated otherwise in a credit line to the material. If material is not included in the article's Creative Commons licence and your intended use is not permitted by statutory regulation or exceeds the permitted use, you will need to obtain permission directly from the copyright holder. To view a copy of this licence, visit http://creativecommons.org/licenses/by/4.0/.

\section{References}

Aarkrog, V. (2005). Learning in the workplace and the significance of school-based education: A study of learning in a Danish vocational education and training programme. International Journal of Lifelong Education, 24, 137-147.

Baartman, L., \& de Bruijn, E. (2011). Integrating knowledge, skills and attitudes: Conceptualising learning processes towards vocational competence. Educational Research Review, 6(2), 125-134.

Baartman, L., Kilbrink, N., \& de Bruijn, E. (2018). VET students' integration of knowledge engaged with in school-based and workplace-based learning environments in the Netherlands. Journal of Education and Work, 31(2), 204-217. https://doi.org/10.1080/13639080.2018.1433821.

Bell, A., \& Mladenovic, R. (2013). How tutors understand and engage with reflective practices. Reflective Practice, 14(1), 1-11. https://doi.org/10.1080/14623943.2012.732949.

Berglund, I., Gustavsson, S., \& Andersson, I. (2020). Vocational teacher students' critical reflections in sitebased education. International Journal of Training Research, 18(1), 22-36. https://doi.org/10.1080/ 14480220.2020 .1747784 .

Berthold, K., Nückles, M., \& Renkl, A. (2007). Do learning protocols support learning strategies and outcomes? The role of cognitive and metacognitive prompts. Learning and Instruction, 17(5), 564577. https://doi.org/10.1016/j.learninstruc.2007.09.007.

Biggs, J. (1988). The role of metacognition in enhancing learning. Australian Journal of Education, 32(2), 127-138. https://doi.org/10.1177/000494418803200201.

Birch, P. D. J., \& Whitehead, A. E. (2020). Investigating the comparative suitability of traditional and taskspecific think aloud training. [article]. Perceptual \& Motor Skills, 127(1), 202-224. https://doi.org/10. $1177 / 0031512519882274$.

Boldrini, E., \& Cattaneo, A. (2014). Scaffolding collaborative reflective writing in a VET curriculum. Vocations and Learning, 7(2), 145-165.

Bonoli, L., Berger, J.-L., \& Lamamra, N. (Eds.). (2018). Enjeux de la formation professionnelle en Suisse. Le " modèle " suisse sous la loupe. Zürich: Seismo.

Bontemps-Hommen, M. C. M. M. L., Baart, A. J., \& Vosman, F. J. H. (2020). Professional workplacelearning. Can practical wisdom be learned? Vocations and Learning. https://doi.org/10.1007/s12186-02009249-X.

Boscolo, P., \& Mason, L. (2001). Writing to learn, writing to transfer. In P. Tynjala, L. Mason, \& K. Lonka (Eds.), Writing as a learning tool: Integrating theory and practice (pp. 83-104). Dordrecht: Kluwer Academic Publishers.

Boud, D., Keogh, M., \& Walker, D. (1985). Reflection: Turning experience into learning. London: Kogan Page.

Burhan-Horasanl1, E., \& Ortaçtepe, D. (2016). Reflective practice-oriented online discussions: A study on EFL teachers' reflection-on, in and for-action. Teaching and Teacher Education, 59, 372-382. https://doi. org/10.1016/j.tate.2016.07.002.

Cattaneo, A., \& Boldrini, E. (2016). Individual and Collaborative Writing-to-Learn Activities in Vocational Education: An Overview of Different Instructional Strategies. In G. Ortoleva, M. Bétrancourt, \& S. Billett (Eds.), Writing for professional development (pp. 188-208). Leiden, The Netherlands: Brill. 
Cattaneo, A., \& Aprea, C. (2018). Visual technologies to bridge the gap between school and workplace in vocational education. In D. Ifenthaler (Ed.), Digital Workplace Learning. Bridging Formal and Informal Learning with Digital Technologies (pp. 251-270). Cham: Springer.

Cattaneo, A., Motta, E., \& Gurtner, J.-L. (2015). Evaluating a mobile and online system for apprentices' learning documentation in Vocational Education: Usability, effectiveness and satisfaction. International Journal of Mobile and Blended Learning, 7(3), 40-58.

Cattaneo, A. A. P., Boldrini, E., \& Lubinu, F. (2020). “Take a look at this!”. Video annotation as a means to foster evidence-based and reflective external and self-given feedback: A preliminary study in operati on room technician training. Nurse Education in Practice, 44, 102770. https://doi.org/10.1016/j.nepr.2020. 102770

Cowan, J. (2017). Linking reflective activities for self-managed development of higher-level abilities. Journal of Perspectives in Applied Academic Practice, 5(1), 67-74. https://doi.org/10.14297/jpaap.v5i1.242.

Cowan, J. (2019). The potential of cognitive think-aloud protocols for educational action-research. Active Learning in Higher Education, 20(3), 219-232. https://doi.org/10.1177/1469787417735614.

Cowan, J. (2020). Students' evidenced claims for development of abilities arising from linked reflection-onaction and reflection-for-action. Reflective Practice, 21(2), 159-170. https://doi.org/10.1080/14623943. 2020.1716709 .

De Bruijn, E., \& Leeman, Y. (2011). Authentic and self-directed learning in vocational education: Challenges to vocational educators. Teaching and Teacher Education, 27, 694-702.

Dewey, J. (1933). How we think: A restatement of the relation of reflective thinking to the educative process. Boston: Health.

Dewey, J. (1938/1963). Experience and education. New York: Macmillan.

Edwards, S. (2017). Reflecting differently. New dimensions: Reflection-before-action and reflection-beyondaction. International Practice Development Journal, 7(1). https://doi.org/10.19043/ipdj.71.002.

Engeström, Y. (1987). Learning by expanding: An activity-theoretical approach to developmental research. Orienta-Konsultit: Helsinki.

Ericsson, K., \& Simon, H. (1980). Verbal reports as data. Psychological Review, 87(3), 215-251.

Ertmer, P. A., \& Newby, T. J. (1996). The expert learner: Strategic, self-regulated, and reflective. Instructional Science, 24(1), 1-24. https://doi.org/10.1007/BF00156001.

Field, A. (2018). Discovering statistics using SPSS (V ed.). London: Sage.

Flavell, J. H. (1979). Metacognition and cognitive monitoring: A new area of cognitive-developmental inquiry. American Psychologist, 34(10), 906-911.

Gavota, M., Cattaneo, A., Arn, C., Boldrini, E., Motta, E., Schneider, D. K., \& Bétrancourt, M. (2010). Computer-supported peer commenting: A promising instructional method to promote skill development in vocational education. Journal of Vocational Education \& Training, 62(4), 495-511.

Hämäläinen, R., \& Cattaneo, A. (2015). New TEL Environments for Vocational Education - Teachers' Instructional Perspective. Vocations and Learning, 8(2), 135-157.

Hatton, N., \& Smith, D. (1995). Reflection in teacher education: Towards definition and implementation. Teaching and Teacher Education, 11, 33-49.

Hetzner, S., Gartmeier, M., Heid, H., \& Gruber, H. (2011). Error orientation and reflection at work. Vocations and Learning, 4(1), 25-39. https://doi.org/10.1007/s12186-010-9047-0.

Holton, J. A., \& Grandy, G. (2016). Voiced inner dialogue as relational reflection-on-action: The case of middle managers in health care. Management Learning, 47(4), 369-390. https://doi.org/10.1177/ 1350507616629602.

Kang, S. H. K. (2016). Spaced repetition promotes efficient and effective learning: Policy implications for instruction. Policy Insights From the Behavioral and Brain Sciences, 3(1), 12-19. https://doi.org/10.1177/ 2372732215624708.

Kaune, C. (2006). Reflection and metacognition in mathematics education - Tools for the improvement of teaching quality. ZDM, 38(4), 350-360. https://doi.org/10.1007/BF02652795.

Kember, D. (2001). Reflective teaching and learning in the health profession. Oxford: Blackwell Publishing.

Kolb, D. (1984). Experiential learning. Experience as the source of learning and development. Englewood Cliffs: Prentice Hall.

Krause, U.-M., \& Stark, R. (2010). Reflection in example- and problem-based learning: Effects of reflection prompts, feedback and cooperative learning. Evaluation \& Research in Education, 23(4), 255-272.

Lavoué, É., Molinari, G., Prié, Y., \& Khezami, S. (2015). Reflection-in-action markers for reflection-on-action in Computer-Supported Collaborative Learning settings. Computers \& Education, 88, 129-142. https:// doi.org/10.1016/j.compedu.2015.05.001.

Leung, D. Y. P., \& Kember, D. (2003). The relationship between approaches to learning and reflection upon practice. Educational Psychology Review, 23(1), 61-71. 
Looi, C.-K., \& Wu, L. (2015). Reflection and preflection prompts and scaffolding. In S. J. Michael (Ed.), The SAGE encyclopedia of educational technology (pp. 610-613). Thousand Oaks: SAGE Publications.

Lukinsky, J. (1990). Reflective withdrawal through journal writing. In J. Mezirow \& Associates (Eds.), Fostering critical reflection in adulthood (pp. 213-234). San Francisco: Jossey-Bass.

Mauroux, L., Dehler Zufferey, J., Rodondi, E., Cattaneo, A., Motta, E., \& Gurtner, J.-L. (2016). Writing reflective learning journals: Promoting the use of learning strategies and supporting the development of professional skills. In G. Ortoleva, M. Bétrancourt, \& S. Billett (Eds.), Writing for professional development (pp. 107-128). Brill.

Mauroux, L., Könings, K. D., Dehler Zufferey, J., \& Gurtner, J.-L. (2014). Mobile and online learning journal: Effects on apprentices' reflection in vocational education and training. Vocations and Learning, 7(2), 215-239.

McKeachie, W. J. (1987). Teaching and Learning in the College Classroom. A Review of the Research Literature (1986) and November 1987 Supplement. Ann Arbor, MI: National Center for Research to Improve Postseconotoxy Teaching and Learning.

Mann, K., Gordon, J., \& MacLeod, A. (2009). Reflection and reflective practice in health professions education: A systematic review. Advances in Health Sciences Education, 14(4), 595-621.

Mezirow, J. (1991). Transformative dimensions of adult learning. San Francisco: Jossey Bass.

Moghaddam, R. G., Davoudi, M., Adel, S. M. R., \& Amirian, S. M. R. (2019). Reflective teaching through journal writing: A study on efl teachers' reflection-for-action, reflection-in-action, and reflection-onaction. English Teaching \& Learning., 44, 277-296. https://doi.org/10.1007/s42321-019-00041-2.

Moon, J. A. (1999a). Reflection in learning and professional development. London: Kogan Page.

Moon, J. A. (1999b). Learning journals: A handbook for academics, students and professional development. London: Kogan Page.

Moon, J. A. (2004). A handbook of reflective and experiential learning. New York: RoutledgeFalmer.

Motta, E., Boldrini, E., \& Cattaneo, A. (2013). Technologies to "bridge the gap" among learning contexts in vocational training. In P. M. Pumilia-Gnarini, E. Favaron, E. Pacetti, J. Bishop, \& L. Guerra (Eds.), Handbook of Research on Didactic Strategies and Technologies for Education: Incorporating Advancements (2 Volumes) (pp. 247-265). Hershey, PA: IGI Global.

Motta, E., Cattaneo, A., \& Gurtner, J.-L. (2014). Mobile devices to bridge the gap in VET: ease of use and usefulness as indicators for their acceptance. Journal of Education and Training Studies, 2(1), 165-179.

Motta, E., Cattaneo, A., \& Gurtner, J.-L. (2017). Co-regulations of Learning in small groups of chef apprentices. When do they appear and what influences them? Empirical Research in Vocational Education and Training, 9:15. https://doi.org/10.1186/s40461-017-0059-y

Ortoleva, G., \& Bétrancourt, M. (2016). Supporting productive collaboration in a computer-supported instructional activity: Peer-feedback on critical incidents in health care education. Journal of Vocational Education \& Training, 68(2), 178-197. https://doi.org/10.1080/13636820.2015.1133693.

Ortoleva, G., Bétrancourt, M., \& Billett, S. (Eds.). (2016). Writing for professional development. Brill.

Raizen, S. A. (1994). Learning and work: The research base. In S. Raizen (Ed.), Vocational education and training for youth: Towards coherent policy and practice (pp. 69-115). Paris: Organisation for Economic Co-operation and Development.

Rock, I. (1958). Repetition and learning. Scientific American, 199(2), 68-76 www.jstor.org/stable/24941082.

Roessger, K. M. (2015). But does it work? Reflective activities, learning outcomes and instrumental learning in continuing professional development. Journal of Education and Work, 28(1), 83-105. https://doi.org/ 10.1080/13639080.2013.805186.

Rogers, C. R. (1961). On becoming a person: A therapist's view of psychotherapy. Boston: Houghton Mifflin.

Rosaen, C. L. (1989). Writing in the content areas: Reaching its potential in the learning process. In J. Brophy (Ed.), Advances in research on teaching: Teaching for meaningful understanding and self-regulated learning (pp. 153-194). Greenwich: JAI Press.

Rose, E. (2016). Reflection in asynchronous online postsecondary courses: A reflective review of the literature. Reflective Practice, 17(6), 779-791. https://doi.org/10.1080/14623943.2016.1220936.

Rosenthal, R. (1991). Meta-analytic procedures for social research (2nd ed.). Newbury Park: Sage.

Schaap, H., Baartman, L. K. J., \& De Bruijn, E. (2012). Students' learning processes during school-based learning and workplace learning in vocational education: A review. Vocations and Learning, 5, 99-117.

Schön, D. A. (1983). The reflective practitioner. How professionals think in action. New York: Basic Books.

Schön, D. A. (1987). Educating reflective practitioners. San Francisco: Jossey-Bass.

Schraw, G., \& Dennison, R. S. (1994). Assessing metacognitive awareness. Contemporary Educational Psychology, 19, 460-475.

Schumacher, G. M., \& Gradwohl Nash, J. (1991). Conceptualizing and measuring knowledge change due to writing. Research in the Teaching of English, 25, 67-96. 
Schwendimann, B., Cattaneo, A., Dehler Zufferey, J., Bétrancourt, M., Gurtner, J.-L., \& Dillenbourg, P. (2015). The 'Erfahrraum': A model for exploiting educational technologies in dual vocational systems. Journal of Vocational Education and Training, 67(3), 367-396.

Schwendimann, B. A., Kappeler, G., Mauroux, L., \& Gurtner, J.-L. (2018). What makes an online learning journal powerful for VET? Distinguishing productive usage patterns and effective learning strategies. Empirical Research in Vocational Education and Training, 10(1), 9.

Segev-Miller, R. (2005). Writing-to-learn: Conducting a process log. In G. Rijlaarsdam, H. Van den Bergh, \& M. Couzijn (Eds.), Effective teaching and learning of writing: A handbook of writing in education (pp. 533-546). Dordrecht: Kluwer.

Stavenga de Jong, J. A., Wierstra, R. F. A., \& Hermanussen, J. (2006). An exploration of the relationship between academic and experiential learning approached in vocational education. British Journal of Educational Psychology, 76, 155-169.

Strahm, R. H., Geiger, B. H., Oertle, C., \& Swars, E. (Eds.). (2016). Vocational and Professional Education and Training in Switzerland. Success factors and challenges for sustainable implementation abroad. Bern, Switzerland: hep Verlag.

Taylor, A., \& Freeman, S. (2011). 'Made in the trade': Youth attitudes toward apprenticeship certification. Journal of Vocational Education \& Training, 63(3), 345-362.

Tigelaar, D., Sins, P., \& van Driel, J. (2017). Fostering students' reflection: Examining relations between elements of teachers' knowledge. Research Papers in Education, 32(3), 353-375. https://doi.org/10.1080/ 02671522.2016 .1225790 .

Thorsen, C. A., \& DeVore, S. (2013). Analyzing reflection on/for action: A new approach. Reflective Practice, 14(1), 88-103. https://doi.org/10.1080/14623943.2012.732948.

van Someren, M. W., Barnard, Y. F., \& Sandberg, J. A. C. (1994). The think aloud method. A practical guide to modeling cognitive processes. London: Academic Press.

Veenman, M. V. J. (2011). Learning to self-monitor and self-regulate. In R. E. Mayer \& P. A. Alexander (Eds.), Handbook of Research on Learning and Instruction (pp. 197-218). Routledge.

Vermersch, P. (2006). L'entretien d'explicitation (V ed.). Paris: ESF.

Vermersch, P. (2009). Describing the Practice of Introspection Journal of Consciousness Studies, 16(10-12), 20-57.

Volet, S., Summers, M., \& Thurman, J. (2009). High-level co-regulation in collaborative learning: How does it emerge and how is it sustained? Learning and Instruction, 19(2), 128-143. https://doi.org/10.1016/j. learninstruc.2008.03.001.

Weibell, C. (2011). Principles of learning: 7 principles to guide personalized, student-centered learning in the technology-enhanced, blended learning environment. Repetition. https://principlesoflearning.wordpress. com/dissertation/chapter-4-results/themes-identified/repetition/

Zhu, X. (2011). Student teachers' reflection during practicum: Plenty on action, few in action. Reflective Practice, 12(6), 763-775. https://doi.org/10.1080/14623943.2011.601097.

Publisher's Note Springer Nature remains neutral with regard to jurisdictional claims in published maps and institutional affiliations.

Dr. Alberto A. P. Cattaneo is professor and head of the research field "Educational Technologies in VET Programmes" at the Swiss Federal Institute for Vocational Education and Training (SFIVET), Switzerland. His actual main research fields concern the integration of ICT in teaching-and-learning processes, reflective learning in VET, instructional design, multimedia learning -especially when it comes to using hypervideos-, teacher education and their professional competence development, in particular related to digital competence.

Dr. Elisa Motta got her PhD at SFIVET working on a project related to the use of technologies to bridge the gap between learning locations in vocational education through the development of metacognitive skills. She is now an independent consultant. 